\title{
Variation of Density and Biomass of the Ichthyofauna Associated to Soft Bottoms of a Western Coastal Lagoon of B.C.S., Mexico
}

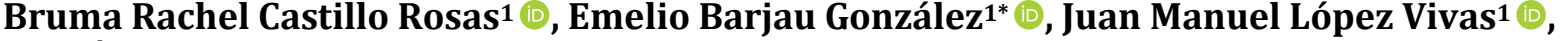 José Ángel Armenta Quintana ${ }^{2}$ (), Javier Aguilar Parra ${ }^{3}$ (), Rodolfo Daniel Acosta Guerrero1, Rogelio Esquivel Tiscareño ${ }^{1}$}

\footnotetext{
${ }^{1}$ Departamento Académico de Ciencias Marinas y Costeras, Universidad Autónoma de Baja California Sur, La Paz, B.C.S. ${ }^{2}$ Departamento Académico de Ciencia Animal y Conservación del Hábitat, Universidad Autónoma de Baja California Sur, La Paz, B.C.S

${ }^{3}$ Departamento Académico de Sistemas Computacionales, Universidad Autónoma de Baja California Sur, La Paz, B.C.S.

Email: rosasr818@gmail.com, *ebarjau@uabcs.mx, jmlopez@uabcs.mx, jarmenta@uabcs.mx, jaguilar@uabcs.mx, roac_19@alu.uabcs.mx, resquivel_20@alu.uabcs.mx
}

How to cite this paper: Rosas, B.R.C., González, E.B., Vivas, J.M.L., Quintana, J.Á.A., Parra, J.A., Guerrero, R.D.A. and Tiscareño, R.E. (2021) Variation of Density and Biomass of the Ichthyofauna Associated to Soft Bottoms of a Western Coastal Lagoon of B.C.S., Mexico. Open Journal of Marine Science, 11, 169-186.

https://doi.org/10.4236/ojms.2021.114011

Received: July 19, 2021

Accepted: October 6, 2021

Published: October 9, 202

Copyright $\odot 2021$ by author(s) and Scientific Research Publishing Inc. This work is licensed under the Creative Commons Attribution International License (CC BY 4.0).

http://creativecommons.org/licenses/by/4.0/

\section{(c) (i) Open Access}

\begin{abstract}
An analysis of the variation of the density and biomass of the fish communities of the lagoon of La Paz, Mexico was carried out from November 2016 to September 2017. A total of 2763 organisms were collected with a total biomass of $211,422.93 \mathrm{~g}$ in an area of $5022 \mathrm{~m}^{2}$, a density and biomass of 0.550 $\operatorname{lnd} / \mathrm{m}^{2}$ and $44.091 \mathrm{~g} / \mathrm{m}^{2}$. The site with the largest biomass was recorded in Zacatecas $\left(11.179 \mathrm{~g} / \mathrm{m}^{2}\right)$ located north of the lagoon, while Grand Plaza recorded the lowest biomass $\left(2.732 \mathrm{~g} / \mathrm{m}^{2}\right)$. Regarding the density, the maximum value was recorded in the site Yate Hundido, located northwest of the lagoon $\left(0.129 \mathrm{lnd} / \mathrm{m}^{2}\right)$ and the lowest was Las Palmas $\left(0.036 \mathrm{lnd} / \mathrm{m}^{2}\right)$ located north of the lagoon. The most abundant species was Diapterus peruvianus with 683 individuals and a biomass of 37,507.57 g. The physicochemical variables showed two seasons with significant change where we can observe higher temperatures in the summer (average of $27.45^{\circ} \mathrm{C}$ ) and minimum in winter (average of $\left.22.49^{\circ} \mathrm{C}\right)$. The Shannon-Weaver diversity index showed a difference $(p=$ $0.050)$ between months, with the highest value recorded in April $\left(H^{\prime}=2.133\right.$ bits/ind) and the lowest in June ( $H^{\prime}=1.041$ bits/ind). The biomass and density values recorded in the lagoon were found to be associated with the spatio-temporal variation of temperature of the lagoon, as well as the resident and transitory species located in the area of study. In addition, the body sizes recorded corresponded to juvenile and young adult individuals.
\end{abstract}




\section{Keywords}

Lagoon of La Paz, Diversity, Abundance, Dominance

\section{Introduction}

The Mexican coast encompasses a wide variety of estuaries, lagoons, and bays with great diversity of fishes. This highlights the relevance of these areas that provide habitat to numerous communities of fishes with potential for fishing, which use these ecosystems as refuge, feeding ground, and nursery [1] [2].

The lagoon of $\mathrm{La} \mathrm{Paz}$ is a coastal lagoon with sites recognized for their oceanographic characteristics like shallow bathymetry, dynamic physicochemical factors, as well as predominance of sandy bottom in its northern region, and mud and dirt in the south region [3]. Regarding its climate, it is semi-desert with predominantly high temperatures coupled with low precipitation contribution, as well as tropical cyclones that are capable to change and remove the substrate [4].

Studies about the biomass and density of the ichthyofauna in coastal lagoons provide information about the impact of anthropogenic factors on such ecosystems, besides it allows us to obtain information about the energy input based on the biomass present during the year, as well as the composition and the trophic structure of fish communities [5] [6] [7]. Moreover, similar studies mention that biomass and density are affected by factors like salinity, temperature, dissolved oxygen, and biotic pressures such as increase and decrease of predators and availability of food, which are important characteristics from the economic and ecological point of view, since these provide a wide variety of ecosystem services [8]. In addition, since the construction of marinas and hotels has increased in the lagoon of La Paz, hydraulic dredging is carried out periodically to facilitate port operations and to allow the entry of all kinds of sailboats and yachts to the marina located next to the hotel Grand Plaza that can cause changes in the structure and diversity of the fish communities that inhabit the area, such as those demonstrated in research related to the study area where it is shown that abiotic and anthropogenic factors intervene in affecting the environment, organisms and therefore both their biological processes [9].

\section{Methods}

\subsection{Area of Study}

The lagoon of La Paz (Figure 1) is located south of the La Paz Bay, in the state of Baja California Sur, between the geographical coordinates $24^{\circ} 11^{\prime}$ and $24^{\circ} 06^{\prime}$ North latitude, and $110^{\circ} 19^{\prime}$ and $110^{\circ} 25^{\prime}$ West longitude. It is separated from the Bay by a sandy barrier denominated "El Mogote" with a length of approximately $11 \mathrm{~km}$ from east-west, and $2.7 \mathrm{~km}$ in its widest area [10]. 


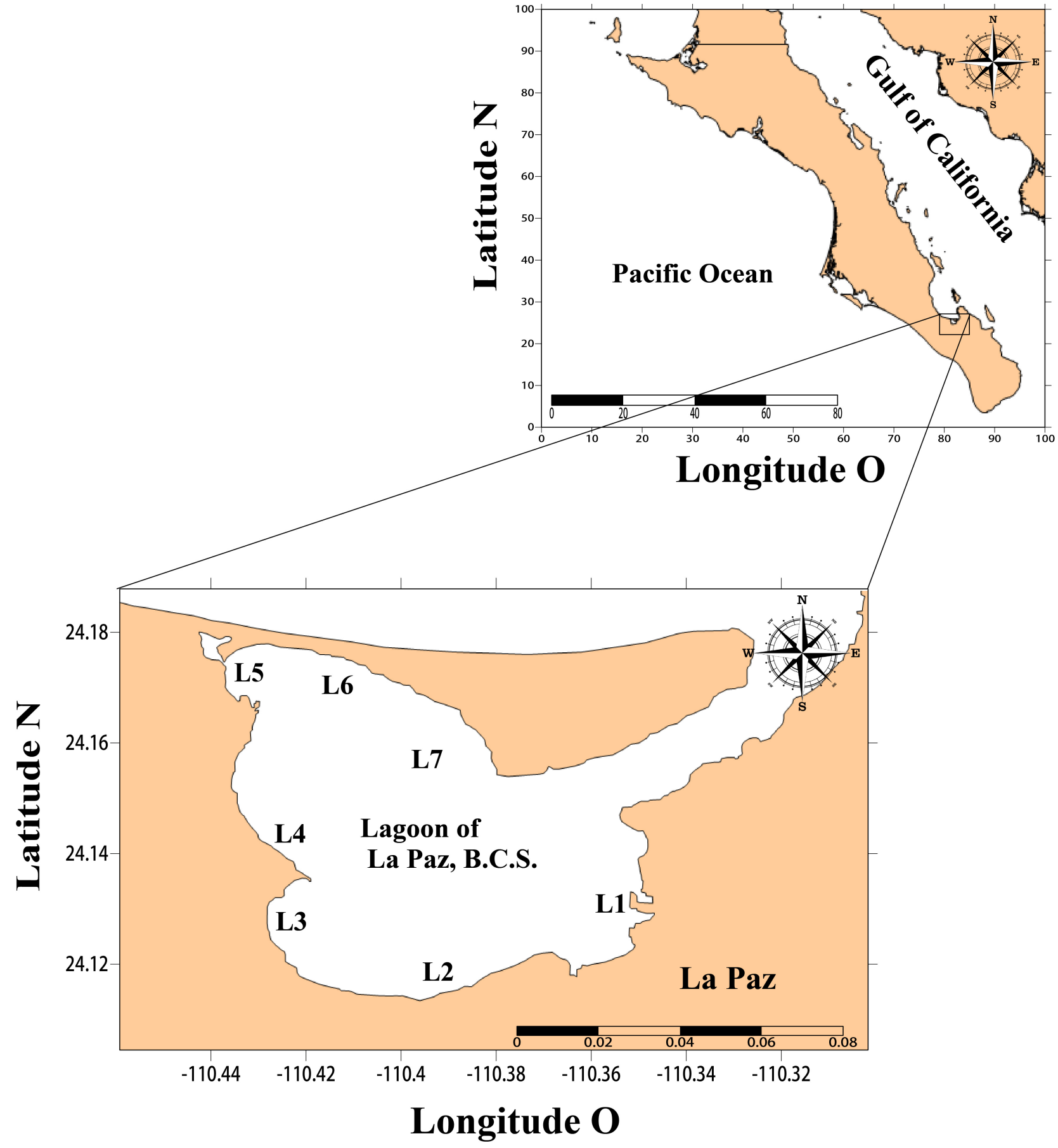

Figure 1. Location of the study area and sampling locations. Grand Plaza (L1), Aeropuerto (L2), Aripez (L3), Cibnor (L4), Zacatecas (L5), Las Palmas (L6), Yate Hundido (L7).

Specimen collection was carried out from November 2016 to September 2017, with a total of 42 replicates from six samplings (one every two months) in seven sites. Collection was carried out using an experimental trawl net with a length of $9.5 \mathrm{~m}$, an opening of $4.5 \mathrm{~m}$, mesh size of $4.44 \mathrm{~cm}$ and $95 \times 50 \mathrm{~cm}$ metal doors. The net is made of polyamide and multifilament and the body of the net is a short tunnel, with a trawling speed of $3.5 \mathrm{~km} / \mathrm{h}$, sweep duration of 20 minutes at 
an average depth of $5 \mathrm{~m}$. A 22-feet-length boat with a $75 \mathrm{HP}$ four-stroke outboard motor, owned by the Autonomous University of Baja California Sur (UABCS). The swept area was set at $5022 \mathrm{~m}^{2}$ (considering the width and distance traveled, as well as depth). Environmental variables like temperature $\left(\mathrm{T}^{\circ}\right)$, salinity (UPS) and dissolved oxygen were recorded at the beginning of each sweep and were taken at a depth of $5 \mathrm{~m}$ with a YSI model 2030 Pro multimeter.

After collection, fish specimens were transferred to the Laboratory of fish ecology at UABCS to be processed. Morphometric measurements of each organism were taken, weight was recorded using a Ohaus Explorer Pro scale, and all specimens were identified to species level using specialized literature. The prepreservation was carried out by injecting $10 \%$ formaldehyde, followed by a rinse with tap water during five days, after which all specimens were preserved in $70 \%$ ethanol.

\subsection{Data Analysis}

Environmental variables were analyzed to test for normal distribution. KruskalWallis test was used to look for significant differences between months and sites.

Biomass was calculated with number of individuals by their average weight [11].

$$
B=g / m^{2}
$$

where $B=$ Biomass, $g=$ grams, $m=$ meters

Density was calculated by the ratio of individuals per unit of volume [12].

$$
D=\mathrm{Ind} / m^{2}
$$

where $D=$ Density, Ind = Individuals, $m=$ meters.

The following ecological analyses were carried out from biomass:

Shannon \& Weaver index $(H)$ is often used when the samples are collected with nets, traps or transects, allowing the comparison of the results with similar studies carried out in other coastal lagoons. This index reflects the heterogeneity of a community based on two metrics: number of species and their relative abundance [13].

$$
H^{\prime}=-\sum(p i)(\ln p i)
$$

where: $H^{\prime}=$ Shannon \& Weaver index, $\ln p i=$ natural logarithm of the total proportion of the sample.

Pielou's evenness index $(J)$ is calculated from the Shannon \& Weaver diversity index $(H)$. It is a component of diversity and an indirect measure of the relative abundance. It uses values from 0 to 1 . Values closer to 1 indicate greater sample evenness, while values closer to 0 indicate unevenness or a greater dominance of some species.

$$
J^{\prime}=H^{\prime} / \ln (S)
$$

where: $J^{\prime}=$ Evenness index, $H^{\prime}=$ Shannon \& Weaver index, $S=$ Number of species. 
Non-metric multidimensional scale (NMDS) is a wide family of multivariate analysis that represent the proximities between a set of elements in a space with a reduced number of dimensions. Thus, it establishes an analogy between proximity (similarity and dissimilarity) and geometric distance, reflecting the differences between both in a function called tension [14].

$$
d_{i j}=\left[\sum_{a-1}^{m}\left|x_{i a}-x_{j a}\right| \lambda\right] \frac{1}{\lambda}
$$

For the interpretation of this analysis, we used the analysis of similarity (ANOSIM) to determine the significant groups using PRIMER V7 and Permutational Multivariate Analysis of Variance Analysis (PERMANOVA).

\section{Results}

\subsection{Environmental Variables}

The temporal structure of the temperature showed significant differences between months $(p<0.05)$. August recorded the highest temperature $\left(28.17^{\circ} \mathrm{C}\right)$ and the lowest was recorded in February $\left(21.43^{\circ} \mathrm{C}\right.$ ) (Figure 2(a)).

The spatial structure of the temperature did not register significant differences between sites $(p=0.9675)$. The lowest value was recorded in Zacatecas $\left(23.28^{\circ} \mathrm{C}\right)$, while the highest value was recorded in Grand Plaza $\left(25.42^{\circ} \mathrm{C}\right)$ (Figure 2(b)).

Salinity did not show significant difference between months $(p=0.6343)$ (Figure $3(\mathrm{a})$ ). The highest value was recorded in October (33.97 UPS), and the lowest in April (31.90 UPS). In addition, salinity did not show significant differences

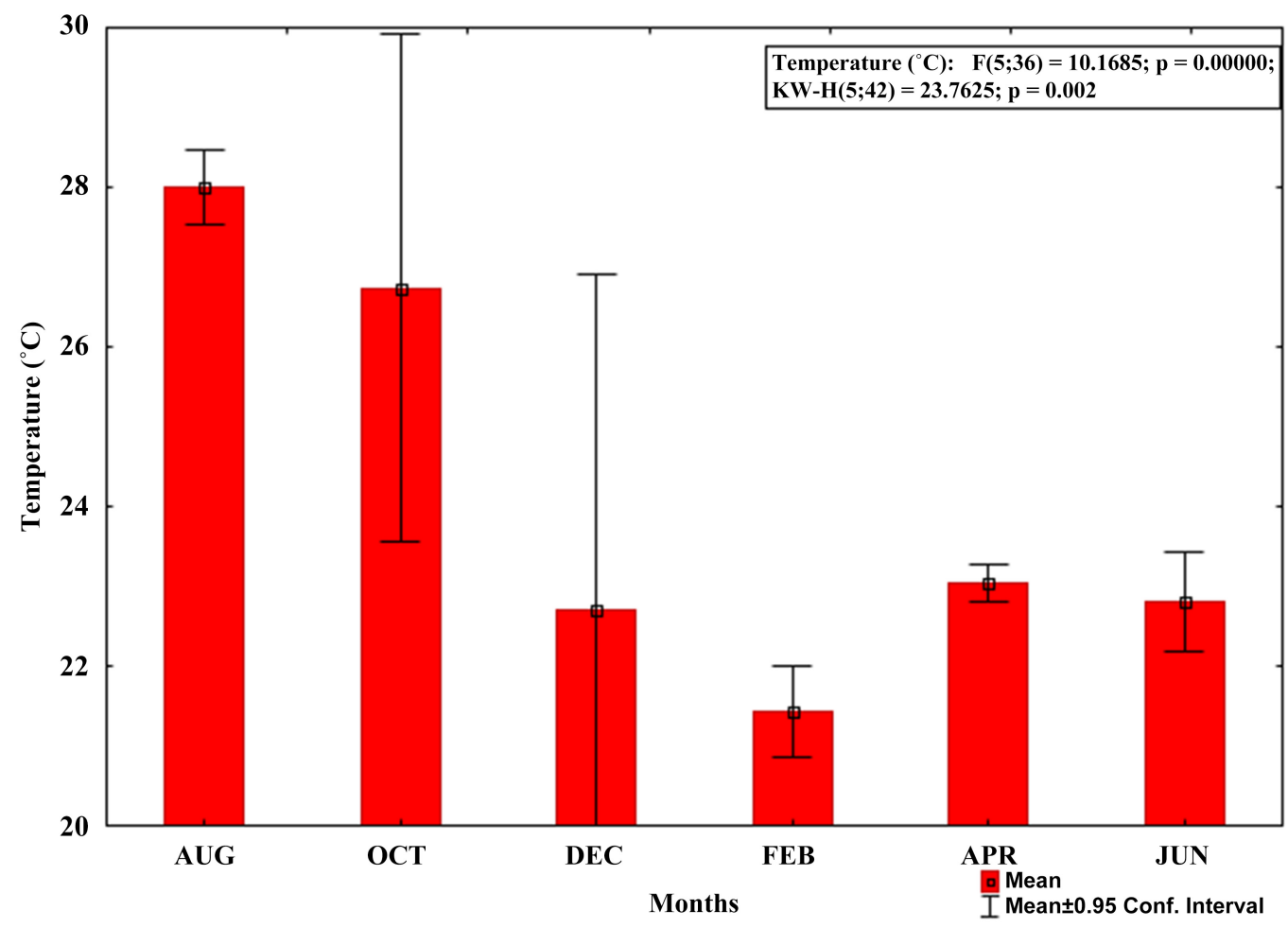

(a) 


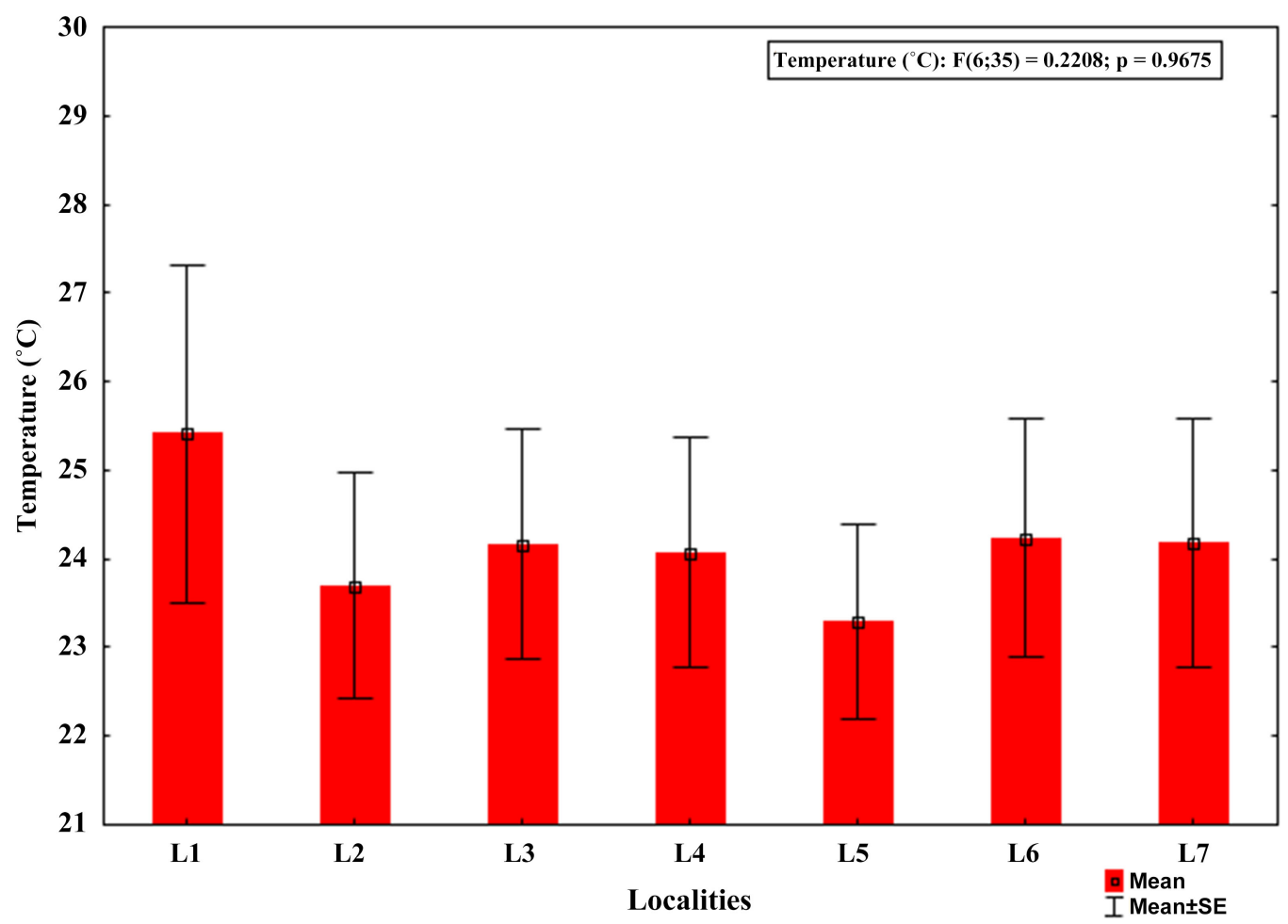

(b)

Figure 2. Temporal and spatial of the temperature of the coastal lagoon of La Paz. Months (a) Aug, Oct, Dec, Feb, Apr, Jun. Localities; (b) Grand Plaza (L1), Aeropuerto (L2), Aripez (L3), Cibnor (L4), Zacatecas (L5), Las Palmas (L6), Yate Hundido (L7).

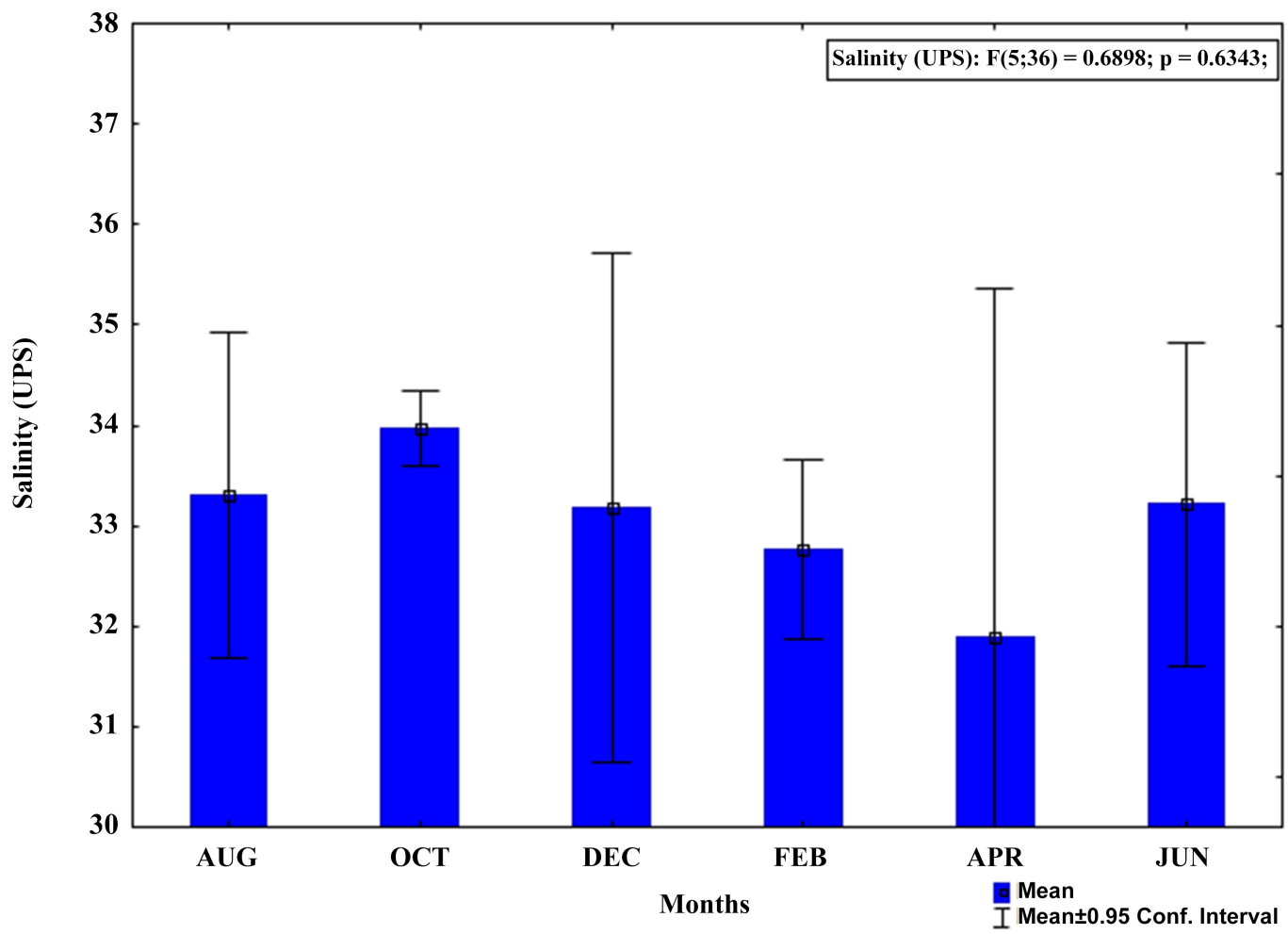

(a) 


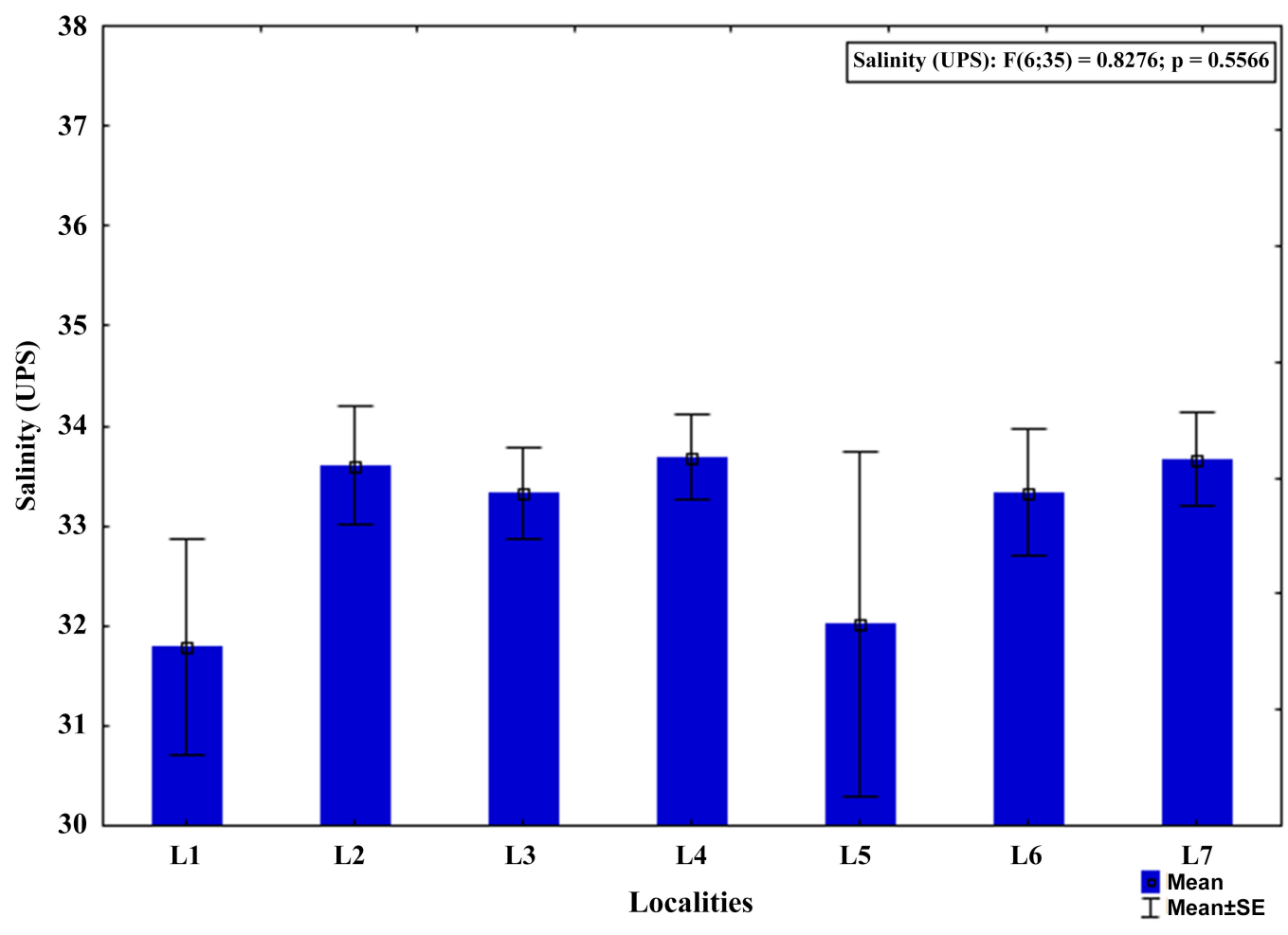

(b)

Figure 3. Temporal and spatial of the salinity of the coastal lagoon of La Paz. Months (a) Aug, Oct, Dec, Feb, Apr, Jun. Localities; (b): Grand Plaza (L1), Aeropuerto (L2), Aripez (L3), Cibnor (L4), Zacatecas (L5), Las Palmas (L6), Yate Hundido (L7).

between sites $(p=0.5756)$ (Figure $3(b))$. The lowest value was recorded in Grand Plaza (31.78 UPS), while the highest was recorded in Cibnor (33.68 UPS).

Dissolved oxygen (DO) did not show significant differences between months $(p<0.5)$. The lowest registry was in August with $12.44 \mathrm{mg} / \mathrm{L}$ and the highest in June with $21.92 \mathrm{mg} / \mathrm{L}$ (Figure 4(a)). The spatial DO did not show significant differences between sites ( $p=0.9095)$, the highest value was recorded in Yate Hundido with $21.25 \mathrm{mg} / \mathrm{L}$, and the lowest value was recorded in Zacatecas with $18.39 \mathrm{mg} / \mathrm{L}$ (Figure 4 (b)).

\subsection{Biomass}

The total weight obtained was $221,422.93 \mathrm{~g}$ which was used to calculate the total biomass of $44.091 \mathrm{~g} / \mathrm{m}^{2}$ with Diapterus peruvianus $\left(16.937 \mathrm{~g} / \mathrm{m}^{2}\right)$ and Paralabrax maculatofasciatus $\left(10.857 \mathrm{~g} / \mathrm{m}^{2}\right)$ as the most representative species. The lowest biomass value was recorded in Aeropuerto $\left(2.732 \mathrm{~g} / \mathrm{m}^{2}\right)$ and the highest in Zacatecas $\left(11.179 \mathrm{~g} / \mathrm{m}^{2}\right)$. The highest value of biomass was recorded in April $(0.343$ $\left.\mathrm{g} / \mathrm{m}^{2}\right)$ and the lowest in August $\left(0.001 \mathrm{~g} / \mathrm{m}^{2}\right)$ (Table 1).

\subsection{Density}

The total area sampled was of $5022 \mathrm{~m}^{2}$, with a total of 2762 individuals, with a density of $0.550 \mathrm{Ind} / \mathrm{m}^{2}$ being the most representative: Diaterus peruvianus $(0.136$ 
Table 1. Species recorded in the lagoon of La Paz: Weight $(\mathrm{g})$, Biomass $\left(\mathrm{kg} / \mathrm{m}^{2}\right) \&$ Density (ind $/ \mathrm{m}^{2}$ ).

\begin{tabular}{|c|c|c|c|c|}
\hline SPECIES & $\begin{array}{c}\text { RELATIVE } \\
\text { ABUNDANCE }\end{array}$ & WEIGHT & $\begin{array}{l}\text { RELATIVE } \\
\text { BIOMASS }\end{array}$ & DENSITY \\
\hline Diapterus peruvianus & 24.728 & $37,507.57$ & 16.937 & 0.136 \\
\hline Paralabrax maculatofasciatus & 12.600 & $24,043.12$ & 10.857 & 0.0693 \\
\hline Eucinostomus argenteus & 8.979 & $21,377.69$ & 9.654 & 0.0494 \\
\hline Haemulon sexfasciatum & 6.626 & 16,100 & 7.270 & 0.0364 \\
\hline Eucinostomus gracilis & 6.553 & $14,144.53$ & 6.387 & 0.036 \\
\hline Eucinostomus currani & 4.055 & $10,941.42$ & 4.941 & 0.0223 \\
\hline Larimus pacificus & 3.657 & $10,652.77$ & 4.811 & 0.0201 \\
\hline Achirus mazatlanus & 3.041 & 9475.2 & 4.279 & 0.0167 \\
\hline Orthopristis chalceus & 2.824 & 8981.13 & 3.990 & 0.0155 \\
\hline Diplectrum pacificum & 2.715 & 7549.02 & 3.409 & 0.0149 \\
\hline Synodus scituliceps & 2.679 & 5902.96 & 2.666 & 0.0147 \\
\hline Urotrygon reticulata & 2.209 & 5133.63 & 2.318 & 0.0121 \\
\hline Haemulon scudderi & 1.991 & 5105.38 & 2.305 & 0.011 \\
\hline Eugerres axillaris & 1.883 & 3181.44 & 1.437 & 0.0104 \\
\hline Anchoa ischana & 1.195 & 3084.9 & 1.393 & 0.0066 \\
\hline Stellifer sp. & 1.086 & 2888.56 & 1.304 & 0.006 \\
\hline Xenichthys californiensis & 1.014 & 2688.87 & 1.214 & 0.0056 \\
\hline Eugerres lineatus & 0.941 & 2622.27 & 1.184 & 0.0052 \\
\hline Urobatis maculatus & 0.905 & 2439.21 & 1.101 & 0.005 \\
\hline Calamus brachysomus & 0.833 & 1958.1 & 0.884 & 0.0046 \\
\hline Eucinosmtomus entomelas & 0.797 & 1922.55 & 0.868 & 0.0044 \\
\hline Anisotremus interruptus & 0.760 & 1872.11 & 0.845 & 0.0042 \\
\hline Syacion ovale & 0.543 & 1688 & 0.762 & 0.003 \\
\hline Orthopristis reddingi & 0.507 & 1558.42 & 0.677 & 0.0028 \\
\hline Sphoeroides annulatus & 0.507 & 1500 & 0.632 & 0.0028 \\
\hline Diodon holocanthus & 0.471 & 1399.99 & 0.535 & 0.0026 \\
\hline Bairdiella icistia & 0.471 & 1185.1 & 0.531 & 0.0026 \\
\hline Haemulopsis leuciscus & 0.434 & 1077.22 & 0.486 & 0.0024 \\
\hline Gerres cinereus & 0.398 & 1026.82 & 0.464 & 0.0022 \\
\hline Serranus psittacinus & 0.362 & 930.8 & 0.420 & 0.002 \\
\hline Trachinotus kennedyi & 0.326 & 860.24 & 0.388 & 0.0018 \\
\hline Lutjanus argentiventris & 0.290 & 827.73 & 0.374 & 0.0016 \\
\hline Microlepidotus brevipinnis & 0.290 & 780.08 & 0.352 & 0.0016 \\
\hline Micropogonias altipinnis & 0.253 & 694.7 & 0.314 & 0.0014 \\
\hline Bagre panamensis & 0.217 & 681 & 0.308 & 0.0012 \\
\hline
\end{tabular}




\section{Continued}

\begin{tabular}{|c|c|c|c|c|}
\hline Paralichthys woolmani & 0.181 & 632.36 & 0.286 & 0.001 \\
\hline Dasyatis brevis & 0.181 & 567.22 & 0.256 & 0.001 \\
\hline Pomadasys panamensis & 0.181 & 535.1 & 0.242 & 0.001 \\
\hline Hippocampus ingens & 0.145 & 515.67 & 0.233 & 0.0008 \\
\hline Cheilotrema saturum & 0.145 & 510.69 & 0.231 & 0.0008 \\
\hline Haemulon steindachneri & 0.109 & 498.59 & 0.225 & 0.0006 \\
\hline Haemulon maculicauda & 0.109 & 450.05 & 0.203 & 0.0006 \\
\hline Umbrina xanti & 0.109 & 422.7 & 0.191 & 0.0006 \\
\hline Lutjanus novemfasciatus & 0.109 & 381.34 & 0.183 & 0.0006 \\
\hline Occidentaruis platypogon & 0.109 & 283.16 & 0.172 & 0.0006 \\
\hline Sphoeroides sechurae & 0.072 & 275.36 & 0.172 & 0.0004 \\
\hline Syclopsetta panamensis & 0.072 & 259.4 & 0.128 & 0.0004 \\
\hline Paraclinis ditrichus & 0.072 & 233 & 0.124 & 0.0004 \\
\hline Pomadasys macracanthus & 0.072 & 215.4 & 0.105 & 0.0004 \\
\hline Opistonema libertate & 0.072 & 196.38 & 0.097 & 0.0004 \\
\hline Cynoscion reticulatus & 0.072 & 187.25 & 0.089 & 0.0004 \\
\hline Urobatis halleri & 0.072 & 187 & 0.085 & 0.0004 \\
\hline Diplectrum labarun & 0.072 & 176.6 & 0.084 & 0.0004 \\
\hline Rhinobatus productus & 0.072 & 135 & 0.080 & 0.0004 \\
\hline Hoplopargus guentheri & 0.072 & 133.7 & 0.061 & 0.0004 \\
\hline Etropus crossotrus & 0.072 & 115.63 & 0.060 & 0.0004 \\
\hline Cyclopsetta panamensis & 0.072 & 103.7 & 0.052 & 0.0004 \\
\hline Paraclinus mexicanus & 0.072 & 75.6 & 0.047 & 0.0004 \\
\hline Urotrygon chilensis & 0.036 & 74.4 & 0.034 & 0.0002 \\
\hline Diodon hystrix & 0.036 & 61.47 & 0.034 & 0.0002 \\
\hline Xenichthys xanti & 0.036 & 60.79 & 0.028 & 0.0002 \\
\hline Prionotus birostratus & 0.036 & 55.1 & 0.027 & 0.0002 \\
\hline Nematistius pectoralis & 0.036 & 53 & 0.025 & 0.0002 \\
\hline Urobatis concentricus & 0.036 & 44 & 0.024 & 0.0002 \\
\hline Caranx speciosus & 0.036 & 43.17 & 0.020 & 0.0002 \\
\hline Haemulopsis axillaris & 0.036 & 40.6 & 0.019 & 0.0002 \\
\hline Cynoscion squamipinnis & 0.036 & 37.7 & 0.018 & 0.0002 \\
\hline Symphurus chabanaudi & 0.036 & 33.88 & 0.017 & 0.0002 \\
\hline Atractoscion nobilis & 0.036 & 33.7 & 0.015 & 0.0002 \\
\hline Prionotus horrens & 0.036 & 24.1 & 0.015 & 0.0002 \\
\hline Pseudopenneus grandisquamis & 0.036 & 8.6 & 0.011 & 0.0002 \\
\hline Chaetodipterus zonatus & 0.036 & 2.46 & 0.004 & 0.0002 \\
\hline Paraclinus sinus & 0.036 & 0.63 & 0.001 & 0.0002 \\
\hline TOTAL & 100 & $221,422.93$ & 100 & 0.55 \\
\hline
\end{tabular}




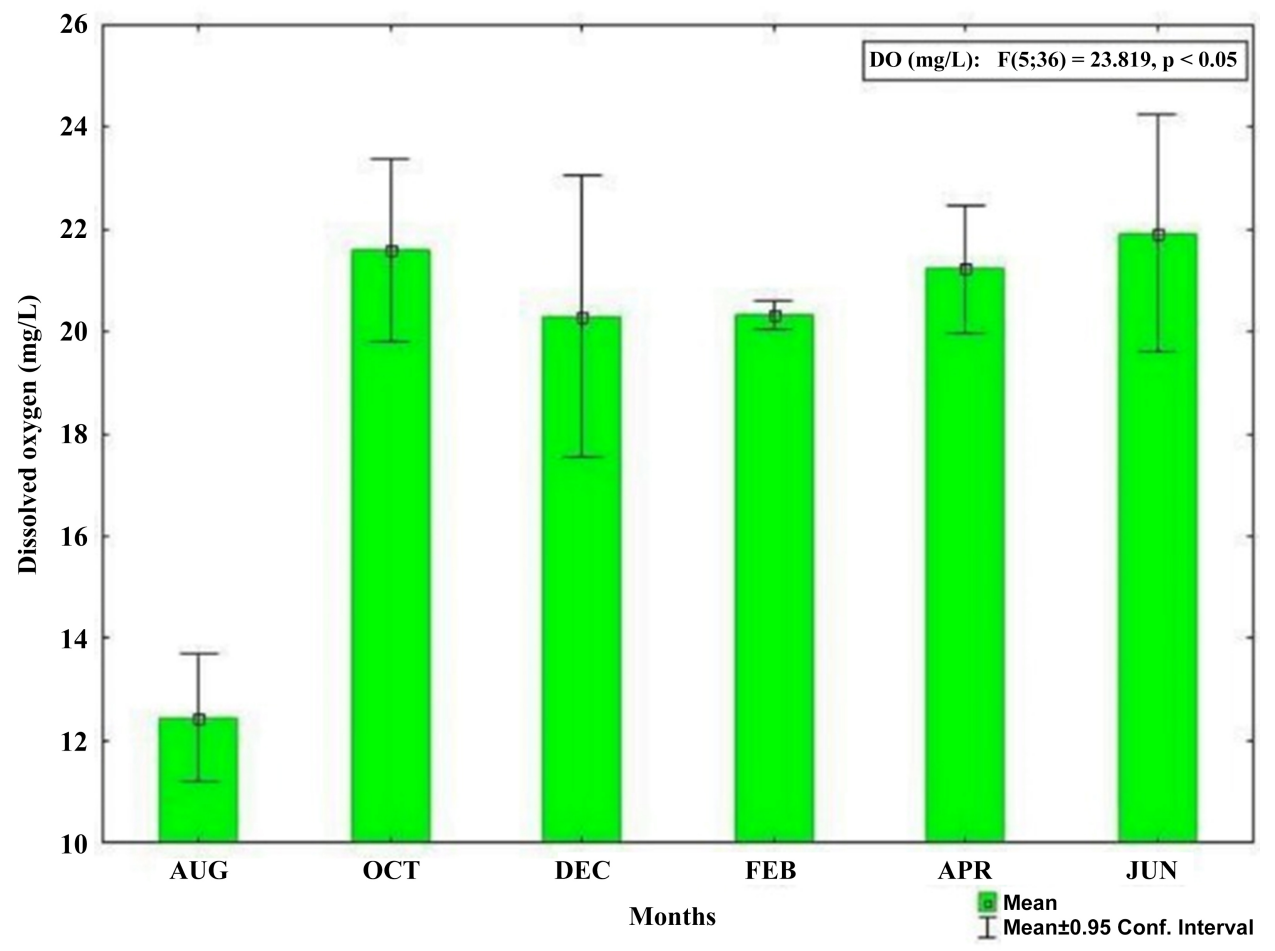

(a)

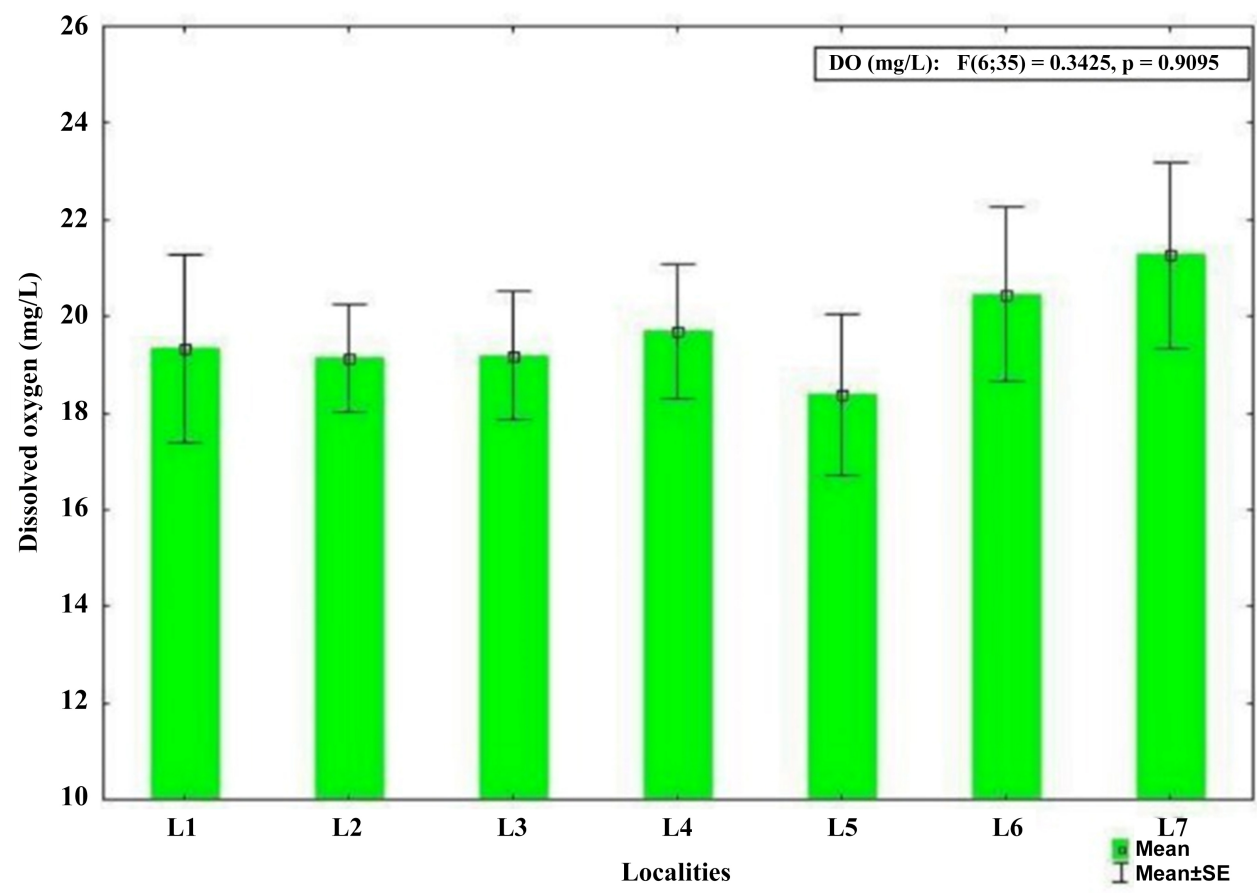

(b)

Figure 4. Dissolved oxygen Months (a) Aug, Oct, Dec, Feb, Apr, Jun. Localities; (b) Grand Plaza (L1), Aeropuerto (L2), Aripez (L3), Cibnor (L4), Zacatecas (L5), Las Palmas (L6), Yate Hundido (L7).

Ind $\left./ \mathrm{m}^{2}\right)$, Paralabrax maculatofasciatus $\left(0.069 \mathrm{Ind} / \mathrm{m}^{2}\right)$ and Eucinostomus argenteus $\left(0.049 \mathrm{Ind} / \mathrm{m}^{2}\right)$. The spatial structure of density showed the highest value in 
Cibnor $\left(0.127 \mathrm{Ind} / \mathrm{m}^{2}\right)$ and a minimum recorded in Grand Plaza $\left(0.044 \mathrm{Ind} / \mathrm{m}^{2}\right)$ and Aeropuerto $\left(0.041 \mathrm{Ind} / \mathrm{m}^{2}\right)$. The temporal structure of density showed the highest value in February $\left(0.193 \mathrm{Ind} / \mathrm{m}^{2}\right)$, while the lowest was recorded in $\mathrm{Au}$ gust $\left(0.034 \mathrm{Ind} / \mathrm{m}^{2}\right)$ (Table 1$)$.

\subsection{Shannon-Weaver Index}

The temporal analysis based on biomass showed significant differences between months $(p=0.0002)$. The highest value of diversity was recorded in April $\left(H^{\prime}=\right.$ $2.133 \mathrm{bits} / \mathrm{ind})$ and the lowest in June $\left(H^{\prime}=1.041 \mathrm{bits} / \mathrm{ind}\right)$ (Table 1). However, the spatial analysis did not show significant differences $(p=0.0508)$. The highest value was recorded in Zacatecas (1.999 bits/ind), while the lowest values were recorded in Grand Plaza $\left(H^{\prime}=0.934\right.$ bits/ind $)$ and Aeropuerto $\left(H^{\prime}=0.934\right.$ $\mathrm{bit} / \mathrm{ind})$.

\subsection{Evenness}

The temporal analysis estimated from the biomass, showed significant differences between months $(p=0.008)$, with the lower values recorded in October $\left(J^{\prime}\right.$ $=0.429)$ and December $\left(J^{\prime}=0.630\right)$, while the remaining months showed a small variation between 0.875 and 0.939 (Table 1 ). The spatial analysis did not show significant differences $(p=0.411)$, the highest value was recorded in Cibnor $\left(J^{\prime}=\right.$ $0.917)$ and the lowest was recorded in Yate Hundido $\left(J^{\prime}=0.488\right)$.

\subsection{Non-Metric Multi-Dimensional Scaling Similarity}

Based on the analysis of NMDS, biomass showed three groups with tension of 0.01, in which April represented a single group, the second group consisted of February, August and December and the third group by June and October. The results of the temporal analysis of similarity (Figure 5(a)) showed August and December with the highest similarities (ANOSIM $=74.324$ ), followed by February (ANOSIM $=72.973$ ) while April showed the lowest similarity compared to other months, which maintained a range from $48 \%$ to $55 \%$ of similarity. The spatial analysis (Figure 5(b)) based on biomass showed five groups with tension of 0.01, in which Aripez represented the first group, the second group consisted of Cibnor and Yate Hundido, the third group was represented by Grand Plaza, the fourth group consisted of Aeropuerto and Las Palmas, and the fifth was re-presented by Zacatecas. The spatial similarity showed Las Palmas with the highest similarity (ANOSIM $=79.452 \%$ ) compared to Aeropuerto, while the lowest value was recorded in Zacatecas (ANOSIM $=46.575 \%$ ) compared to Aripez.

\section{Discussion}

\subsection{Environmental Variables}

The temporal relation abundance-temperature was defined by temperature. The temporal analysis showed an increase from August to October, with an average 


\section{Temporal}

Months

Transform: Square root Resemblance: S1 Simple matching

3D Stress: 01

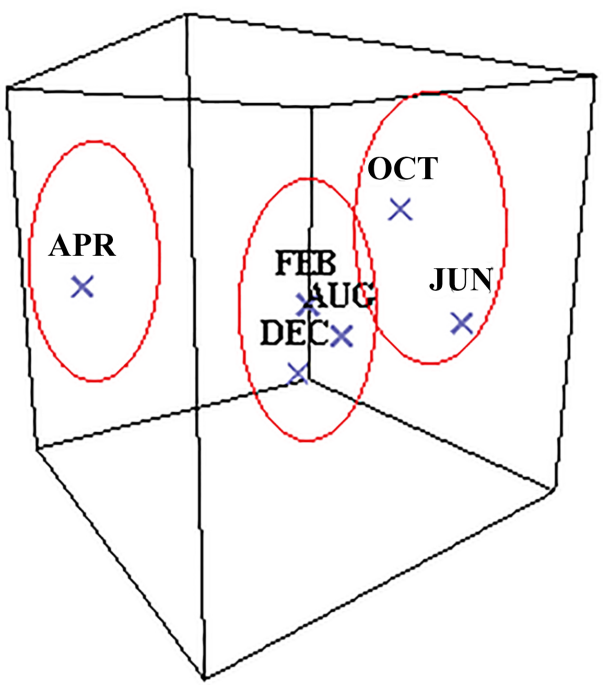

(a)

\section{Spatial}

\section{Localities}

Transform: Square root

Resemblance: S1 Simple matching

3D Stress: 0.01

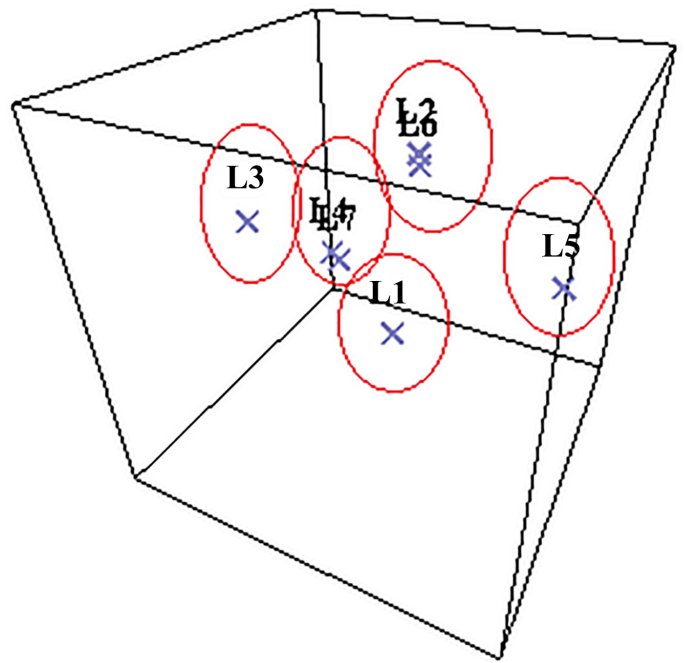

(b)

Figure 5. Temporal and spatial of the Non-Metric Multi-Dimensional Scaling (NMDS) of the coastal lagoon of La Paz. 
of $27.45^{\circ} \mathrm{C}$, and a decrease from December to June, with an average of $22.49^{\circ} \mathrm{C}$, favoring the entrance of fish species with subtropical affinity during the first period, and the entrance of fish species with temperate affinity during the second period, similar to a previous report by Gomez-Leo [15] who mentioned that the coldest months are January and February with an average temperature of $20^{\circ} \mathrm{C}$. Moreover, a study by Barjau-González [16] in the bay adjacent to the lagoon of La Paz, showed that the warmest months allow ideal conditions to increase the coverage, biomass and associated fauna. In another study of a coastal lagoon in the gulf of California, showed that there is a seasonal pattern similar to the one found in the present study, finding that the warmest month is in September with an average of $33.5^{\circ} \mathrm{C}$ and a minimum in February with an average of $17.5^{\circ} \mathrm{C}$ [17]. The spatial analysis of temperature did not show significant differences between sites, but a slight increase was observed between sites. On the other hand, Gomez-Leon [15] mentioned that the temperature has a variation of approximately $4^{\circ} \mathrm{C}$ inside the lagoon, in which the northwest part tends to have a temperature of $30^{\circ} \mathrm{C}$ and the southwest a record of $26^{\circ} \mathrm{C}$. These variations are caused by the water masses that enter and exit the lagoon throughout the day, which influence the arrival and departure of fish fauna [18].

The temporal analysis of salinity did not show differences between months, however, a study by Gonzalez-Acosta [19] in the lagoon of La Paz, mentioned that there is an evaporation of $33 \%$ that increases to $55 \%$ during spring. On the other hand, the spatial analysis of salinity showed differences between sites. Barjau-González [16] mentioned that in the Bay of La Paz the salinity increases in shallow areas and decreases in deeper areas. Since the lagoon of $\mathrm{La} \mathrm{Paz}$ is considered a shallow area, this suggests is a hypersaline lagoon, with low contributions of freshwater and a high degree of evaporation, therefore, high values of salinity are common.

The temporal pattern of $\mathrm{DO}$ was considered stable during the year, while the spatial DO showed differences, which can be explained by the differences of depth between the sampled sites, showing a higher saturation in shallow areas and lower in deeper areas. Gutiérrez-Sánchez [20] reports a difference between physicochemical factors in the lagoon complex Bahia Magdalena, due to oceanic influence, bathymetry, and differential evaporation, which he describes as the most important factors that influence the lagoon complex.

\subsection{Biomass}

This study shows a higher biomass compared to similar studies. Macias [8] who estimated a maximum biomass of $2.99 \mathrm{~kg} / \mathrm{m}^{2}$ in Laguna Madre. Romero-González [21] in a study of biomass in adjacent beaches to the Bay of La Paz, showed that those beaches with smaller size have greater biomass, while beaches with greater extension are influenced by the currents of the San Lorenzo Canal, therefore, showing a higher primary productivity and a greater biomass during the warmer months. This variation may be due to the environmental conditions of the lagoon of $\mathrm{La} \mathrm{Paz}$, the movement of organisms determined by the heterogeneity of 
the habitat and their zoogeographic affinity that allows the arrival and departure of the same organisms. In addition, since it is a lagoon that presents fish species of small sizes, it can be inferred that the lagoon is used as an area for growth, reproduction and feeding, which according to González-Acosta [19], this is because of the predominantly shallow areas in the lagoon. Barjau-González [16] mentioned that biotic and abiotic factors are related to the physical, chemical, and biological conditions of the lagoon, that influence the variation of biomass. Melendez and Alejandra [22] explain that variations of biomass and density depend on the architecture of the habitat and the ability of organisms to adapt, which is reflected in the spatial distribution of biomass according to temperature. In addition, these variations of biomass suggest seasonality of the resident and transient species of the lagoon, because of the seasonal environmental changes.

\subsection{Density}

The density recorded in the present study was similar to the one obtained by Macias [8], who determined density of the ichthyofauna in the Laguna Madre. This can be explained by the composition of the species found within this lagoon, alongside its hypersalinity and shallow areas, mainly composed of silt-clayey substrates. Barjau-González [16] mentioned that the complexity of the communities in terms of abundance depends on the complexity of the habitat, the food, mobility of the fish, reproduction, and environmental conditions, which is reflected in the results, having seasons of both, high and low density [23]. This is also observed in the values of density obtained, since they show a seasonal pattern consistent with the temporal distribution of temperature [24].

\subsection{Shannon-Weaver Index}

The diversity index showed significant differences. April recorded the lowest value, while the highest was recorded in October. Based on our results, diversity of the seven sites sampled in the lagoon of $\mathrm{La} \mathrm{Paz}$ is considered low, which is consistent with reports by Spellerberg and Fedor [25], who mentioned that any values of diversity less than three are considered low. Furthermore, Romero-González [21] mentions that diversity increases during winter on beaches in the bay adjacent to the lagoon of La Paz, which is consistent with our results since the higher values of diversity were recorded in the colder months. This can be explained by the temporality and thermal affinity of the ichthyofauna. Gómez León [15] analyzed the diversity in the Gulf of California, finding dominance of fewer species during the winter and summer periods, which is explained by the influence of environmental factors, such as the weather and the availability of food.

Malpica-Maury [26] found higher diversity during winter, while Barjau-González [16] carried out a similar study finding a seasonal relationship with species recorded during summer. In addition, Rodríguez-Romero et al. [27] found a high diversity during April and a low diversity during October in a study made in the Rancho Bueno lagoon, near Magdalena Bay, directly related to the temperature factor which directly influences the diversity. Acevedo-Cervantes [28] made a 
study in Ojo de Liebre lagoon in the north of B.C.S. Using a hook line fishing technique, registering a higher diversity during March and the lowest during September. However, using a trawl net, the highest values were recorded in September while the lowest were recorded in July. This suggests temporal preferences, which are consistent with times of high and low productivity, where the number of species tend to increase, as food availability also increases, as well as the start of the breeding season.

Regarding the spatial-analysis, diversity did not show significant differences, however, the site with the highest value was Zacatecas, which is located north of the lagoon, while the location of Aeropuerto recorded the minimum and is located to the south of the lagoon. Based on these patterns of variation, diversity of the area is influenced by resident and transient species found in the area, depending on the substrate and the site of the lagoon. In comparison, Romero-González [21] mentioned that sites with the greatest diversity are those protected compared to extensive sites without protection. This is consistent with the sites sampled in this study, especially those with maximums and minimums values.

\subsection{Evenness}

According to the temporal-analysis of evenness, lowest values were recorded in June and December, opposite results to what was found by Malpica-Maury [26] with higher values during winter and low during summer. This is caused by the dominance of the different species of fish in the area. In addition, Barjau-González [16] also found significant differences, finding higher evenness values during June and lower during August. This may be due to different species moving in and out of the lagoon, causing variation in their abundance due to environmental changes.

According to the spatial analysis, no significant differences were found between sites, lower values were recorded in Aeropuerto and Yate Hundido. Opposite results to a study carried out in the Bay of La Paz by Barjau-González [16], who found differences between sites, which is due to the distribution and preferences of the species, since some shallow areas are used as feeding grounds depending on the time of day and others as shelter and rest. A similar study by Barjau-González [29] and Muñoz-Félix [24], was done in the San Ignacio lagoon, finding low evenness values.

\subsection{Non-Metric Multi-Dimensional Scaling}

The NMDS analysis in its temporal structure, formed two groups, with April standing out as a single group. Minimum variations of temperature were recorded during this month, while the sites with higher temperatures were included in the second group. Contrary to what was found by Padilla-Serrato [17], with four groups in the Las Guásimas lagoon in Sonora that correspond to the weather seasons. On the other hand, Quiroz-Vázquez et al. [30] in the same San Quintín Bay recorded higher temperatures from April to October and the second 
one to February-November with the lowest temperatures, therefore, temperature fluctuations can explain the diversity and density of organisms, however, it can also be explained by the cyclical and seasonal species typically present in the lagoon, which use it as feeding ground and protection from predators during the first stages of life.

\section{Conclusion}

The spatiality and temporality pattern of the physicochemical variables of the La Paz lagoon influenced the variation of biomass, density, diversity, richness and similarity of the fish communities associated with soft bottoms. Therefore, we can infer that biomass has a cyclical behavior, influenced on the one hand by environmental variables and on the other, the presence of seasonal and resident species that make up the lagoon, which is defined by their own biological processes (feeding, reproduction, safeguard, etc.). And consequently, they maintain the ecosystem balance, since it has been considered that fish are used as indicators of ecological health in aquatic ecosystems, maintaining their interspecific and intraspecific relationships through the transfer of energy with the addition of other members of the fauna present in the zone.

\section{Authors Contribution}

BRC co-wrote the manuscript with EBG, RET, RDAG, JAP. EGB and BRCR carried out fish collection, identification, and data analysis. EBG contributed to the project and the revisions. All authors read and approved the final manuscript. Also, they all declare that they have not conflict of interest.

\section{Acknowledgements}

The authors thank Universidad Autónoma de Baja California Sur (UABCS) for allowing the use of its facilities (Laboratory of Fish Ecology) and for sponsoring this project.

\section{Conflicts of Interest}

The authors declare no conflicts of interest regarding the publication of this paper.

\section{References}

[1] Macías, E.B. (1999) Variación de la densidad y la biomasa de peces juveniles y decápodos epibénticos de la región central de Laguna Madre, Tamaulipas. Hidrobiológica, 9, 103-116.

[2] Cabrera-Páez, Y., Aguilar-Betancourt, C.M. and González-Sansón, G. (2020) Influencia del sustrato en la composición de la ictiofauna en zonas someras de la laguna costera Barra de Navidad, México. Revista de Biología Tropical, 68, 1322-1336. https://doi.org/10.15517/rbt.v68i4.42139

[3] Cervantes Duarte, R., Aguirre Bahena, F., Reyes Salinas, A. and Valdez Holguín, J.E. (2001) Caracterización hidrológica de una laguna costera de Baja California Sur, 
México. Oceánides, 16, 93-105.

[4] Turrén-Cruz, T., Benegas, L., Gutiérrez-Montes, I. and Brenes, C. (2019) Evaluación de la vulnerabilidad ante eventos climáticos extremos, en La Paz, Baja California Sur; México. CIENCIA ergo-sum, 26, No. 1. https://doi.org/10.30878/ces.v26n1a6

[5] Núñez-Lara, E. and Arias González, J.E. (1998) Composición, Biomasa y Estructura Trófica de la Comunidad de Peces Arrecifales en Tres Areas del Sur del Caribe Mexicano. Proceedings of the 50 th Gulf and Caribbean Fisheries Institute, Merida, Mexico, 1998, 1003-1021.

[6] Galván-Villa, C.M. (2015) Estructura de los ensamblajes de peces arrecifales de tres áreas marinas protegidas del pacífico mexicano. Ecosistemas y Recursos Agropecuarios, 2, 69-86.

[7] Ayala-Pérez A.L., Ramos Miranda, J. and Flores Hernández, D. (2003) La comunidad de peces de la Laguna de Términos: Estructura actual comparada. Revista de Biología Tropical, 51, 783-793.

[8] Macías, E.B. (1999) Variación de la densidad y la biomasa de peces juveniles y decápodos epibénticos de la región central de Laguna Madre, Tamaulipas. Hidrobiológica, 9, 103-116.

[9] Castillo-Rosas, B.R., Barjau-González, E., López-Vivas, J.M., Romo-Piñeda, A.K., Romero-Vadillo, E. and Armenta-Quintana, J.Á. (2020) Structure of the Community of Dominant Fish Species Associated to Soft-Bottoms in the Lagoon of La Paz, B.C.S., México. Open Journal of Marine Science, 10, 79-92. https://doi.org/10.4236/ojms.2020.103006

[10] Cervantes-Duarte, R. and Guerrero-Godínez, R. (1988) Variación espacio-temporal de nutrientes de la Ensenada de La Paz, B.C.S., México. Anales del Instituto de Ciencias del Mar y Limnología, 15, 129-142.

[11] Arnáiz Franco, C., Isac Oria, L. and Lebrato Martínez, J. (2000) Determinación de la biomasa en procesos biológicos. I Métodos directos e indirectos. Tecnología del agua, 20, 45-52.

[12] González Acosta, A.F. (1998) Ecología de la comunidad de peces asociada al manglar del Estero El Conchalito, Ensenada de La Paz, Baja California Sur, México. Doctoral Dissertation, Instituto Politécnico Nacional Centro Interdisciplinario de Ciencias Marinas.

[13] Thomson, D.A., Findley, L.T. and Kerstitch, A.N. (2000) Reef Fishes of the Sea of Cortez. University of Texas Press, Austin, 375 p. https://doi.org/10.7560/781542

[14] López-González, E. and Sánchez, R.H. (2010) Escalamiento Multidimensional No Métrico. Un ejemplo con R empleando el algoritmo SMACOF. Estudios Sobre Educación, 18, 9-35.

[15] Gómez León, A.A. (2018) Variabilidad en la abundancia relativa de foraminíferos bentónicos: Indicador de la calidad de los sedimentos en la Laguna de La Paz, Golfo de California. Doctoral Dissertation, Instituto Politécnico Nacional Centro Interdisciplinario de Ciencias Marinas.

[16] Barjaú-González, E. (2012) Estructura combbunitaria y diversidad taxonómica de los peces en la Bahía de la Paz y la Isla San José, Golfo de California.

[17] Padilla-Serrato, J., López-Martínez, J., Rodríguez-Romero, J., Acevedo-Cervantes, A., Galván-Magaña, F. and Lluch-Cota, D. (2017) Variaciones en la estructura comunitaria de peces en una laguna costera del Golfo de California, México. Revista de Biología Marina y Oceanografía, 52, 567-579.

https://doi.org/10.4067/S0718-19572017000300013 
[18] Sánchez-Velasco, L., Jiménez-Rosenberg, S.P.A., Shirasago, B. and Obeso-Nieblas, M. (2004) Distribution and Abundance of Fish Larvae in Bahia De La Paz (Gulf of California) and Their Relation to Hydrographic Variability during Summer (1997-1998). Deep Sea Research Part II: Topical Studies in Oceanography, 51, 723-737. https://doi.org/10.1016/j.dsr2.2004.05.020

[19] González Acosta, A.F. (1998) Ecología de la comunidad de peces asociada al manglar del Estero El Conchalito, Ensenada de La Paz, Baja California Sur, México. Doctoral Dissertation, Instituto Politécnico Nacional Centro Interdisciplinario de Ciencias Marinas.

[20] Gutiérrez Sánchez, F.J. (1997) Ecología de peces de fondos blandos del complejo lagunar Bahía Magdalena, BCS, México. Doctoral Dissertation, Instituto Politécnico Nacional Centro Interdisciplinario de Ciencias Marinas.

[21] Romero González, A.C. (2018) Efecto del ambiente en la comunidad intermareal de playas arenosas protegidas en la Bahía de La Paz, BCS, México. Doctoral Dissertation, Instituto Politécnico Nacional Centro Interdisciplinario de Ciencias Marinas.

[22] Meléndez, C., y Alejandra, C. (2018) Fauna asociada a praderas de pasto marino Halodule wrightii de Punta Roca Caimancito, de la Ensenada de La Paz, BCS. Bachelor's Thesis, Benemérita Universidad Autónoma de Puebla.

[23] Rodríguez Romero, J. (1992) Composición, abundancia y riqueza específica de peces de fondos blandos en Bahía Concepción Baja California Sur, México durante el periodo febrero-septiembre de 1989. Doctoral Dissertation, Instituto Politécnico Nacional Centro Interdisciplinario de Ciencias Marinas.

[24] Muñoz-Félix F.A. (2017) Estructura de la comunidad de peces asociados a fondos blandos y su papel ecológico en la Laguna San Ignacio, BCS, México. UABCS_CICIMAR.

[25] Spellerberg, I.F. and Fedor, P.J. (2003) A Tribute to Claude Shannon (1916-2001) and a Plea for More Rigorous Use of Species Richness, Species Diversity and the 'Shannon-Wiener' Index. Global Ecology and Biogeography, 12, 177-179. https://doi.org/10.1046/j.1466-822X.2003.00015.x

[26] Malpica-Maury, O.M. (1999) Íctiofauna de la Ensenada de La Paz, BCS, México. Doctoral Dissertation, Instituto Politécnico Nacional Centro Interdisciplinario de Ciencias Marinas.

[27] Rodríguez-Romero, J., López-González, L.D.C., Galván-Magaña, F., Sán-chez-Gutiérrez, F.J., Inohuye-Rivera, R.B. and Pérez-Urbiola, J.C. (2011) Cambios estacionales de la comunidad de peces asociada a zonas de manglar en una laguna costera de Baja California Sur, México. Latin American Journal of Aquatic Research, 39, 250-260.

[28] Acevedo-Cervantes, A. (1997) Caracterización ecológica de la comunidad íctica de la Laguna Ojo de Liebre, BCS México. Doctoral Dissertation, Instituto Politécnico Nacional Centro Interdisciplinario de Ciencias Marinas.

[29] Barjaú-González, E. (2003) Estructura de la íctiofauna asociada a fondos blandos en laguna san Ignacio, baja california sur, México (maestría). Instituto Politécnico Nacional Centro Interdisciplinario de Ciencias Marinas.

[30] Quiroz-Vázquez, P., Ibarra-Obando, S.E. and Meling-Lopez, A.E. (2005) Composition of the Epifaunal Community Associated with the Seagrass Zostera Marina in San Quintin Bay, Baja California. Bulletin of the Southern California Academy of Sciences, 104, 100-112. https://doi.org/10.3160/0038-3872(2005)104[100:COTECA]2.0.CO;2 